\title{
Hardening Properties of Cheeses by Latilactobacillus curvatus PD1 Isolated from Hardened Cheese-Ddukbokki Rice Cake
}

\author{
Jeong-A. Kim, Geun-Su Kim, Se-Mi Choi, Myeong-Seon Kim, Do-Young Kwon, Sang-Gu Kim, Sang-Yun Lee \\ and Kang-Wook Lee *(D)
}

check for

updates

Citation: Kim, J.-A.; Kim, G.-S.; Choi, S.-M.; Kim, M.-S.; Kwon, D.-Y.; Kim,

S.-G.; Lee, S.-Y.; Lee, K.-W. Hardening

Properties of Cheeses by

Latilactobacillus curvatus PD1 Isolated from Hardened Cheese-Ddukbokki Rice Cake. Microorganisms 2021, 9, 1044. https://doi.org/10.3390/ microorganisms 9051044

Academic Editors: Mariantonietta Succi and Elena Sorrentino

Received: 30 March 2021

Accepted: 10 May 2021

Published: 12 May 2021

Publisher's Note: MDPI stays neutral with regard to jurisdictional claims in published maps and institutional affiliations.

Copyright: (c) 2021 by the authors. Licensee MDPI, Basel, Switzerland. This article is an open access article distributed under the terms and conditions of the Creative Commons Attribution (CC BY) license (https:// creativecommons.org/licenses/by/ $4.0 /)$.
Pulmuone Institute of Technology, Cheongju 28164, Korea; crystal.kim01@pulmuone.com (J.-A.K.); gskimb@pulmuone.com (G.-S.K.); smchoi@pulmuone.com (S.-M.C.); sunny.kim01@pulmuone.com (M.-S.K.); dykwon@pulmuone.com (D.-Y.K.); sgkimn@pulmuone.com (S.-G.K.); sylee@pulmuone.com (S.-Y.L.)

* Correspondence: kwook49@gmail.com; Tel.: +82-010-9392-4694; Fax: +82-02-772-1909

\begin{abstract}
Hardening of cheese is one of major issues that degrade the quality of Home Meal Replacement (HMR) foods containing cheese such as Cheese-ddukbokki rice cake (CD, stir-fried rice cakes with shredded cheese). The quality of cheese, such as $\mathrm{pH}$, proteolytic, and flavor properties, depends on various lactic acid bacteria (LAB) used in cheese fermentation. The hardening of cheese is also caused by LAB. In this study, various LAB strains were isolated from CD samples that showed rapid hardening. The correlation of $L A B$ with the hardening of cheese was investigated. Seven of the CD samples with different manufacturing dates were collected and tested for hardening properties of cheese. Among them, strong-hardening of cheese was confirmed for two samples and weak-hardening was confirmed for one sample. All LAB in two strong-hardening samples and 40\% of LAB in one weak-hardening sample were identified as Latilactobacillus curvatus. On the other hand, most LAB in normal cheese samples were identified as Leuconostoc mesenteroides and Lactobacillus casei. We prepared cheese samples in which L. curvatus (LC-CD) and L. mesenteroides (LM-CD) were most dominant, respectively. Each CD made of the prepared cheese was subjected to quality test for 50 days at $10{ }^{\circ} \mathrm{C}$. Hardening of cheese with LC-CD dominant appeared at 30 days. However, hardening of cheese with LM-CD dominant did not appear until 50 days. The $\mathrm{pH}$ of the LC-CD was $5.18 \pm 0.04$ at 30 days, lower than that of LM-CD. The proteolytic activity of LC-CD sample was $2993.67 \pm 246.17$ units $/ g$, higher than that of LM-CD sample (1421.67 \pm 174.5 units $/ g)$. These results indicate that high acid production and high protease activity of L. curvatus might have caused hardening of cheese.
\end{abstract}

Keywords: cheese; cheese hardening; Latilactobacillus curvatus; cheese-ddukbokki rice cake

\section{Introduction}

Cheese is a fermented dairy product made by coagulating casein, removing whey, compressing and molding by adding lactic acid bacteria (LAB), rennet, and acid to milk or cream. Cheeses are manufactured through several steps, such as gel-forming, whey expulsion, salt addition, and acid production [1,2]. The quality of cheese differs depending on the raw milk, microorganisms, enzymes, and processes used for manufacturing, and the manufacturing region. It has been reported that approximately 1000 kinds of cheese or more are produced worldwide [2]. Types of cheese are generally classified according to characteristics of the cheese. Cheese can be classified into soft, semi-soft, semi-hard, and hard cheese depending on its moisture content and the texture. Cheese typically shows three forms when heated, including a stretchy form with a property that stretches like rubber, a creamy form, and a non-melting form that crumbles [3].

In Korea, according to statistical results of types of cheese purchased by consumers in 2015, shredded cheese is widely consumed as one of the preferred cheese types for all age groups $[4,5]$. However, shredded cheese has a larger surface area than other types of cheese. Its quality is relatively unstable due to rapid moisture reduction, rancidification, 
and over-fermentation by microorganisms. To maintain the quality of cheese, adding preservatives and filling gas are performed during cheese processing and packaging stages. For shredded cheese that is usually stored at $0-10{ }^{\circ} \mathrm{C}$, a mixture of nitrogen and carbon dioxide is filled inside the package [6]. Cellulose powder is generally used as an anti-caking agent during the shredding process. [3]. Shredded cheese is widely used in home meal replacement foods (HMR). Korean traditional types of HMR foods such as $d d u k b o k k i$ (spicy stir-fried rice cakes), kimchi-jeon (Kimchi pancake), and cheese ball (fried cheese bread) are very popular. They are exported to other countries such as United States, Japan, and China. With increasing demand for HMR foods with cheese, there are also many manufacturing methods. Therefore, types of final food products have become very diverse depending on the processing method, the storage method, and the type of raw materials. It is very important to maintain the best quality of each product.

Ddukbbokki is one of Korea's traditional types of HMR foods. It is prepared with $d d u k$ (rice cake) and seasoning, like soy sauce, sugar, and kochujang. Ddukbokki-dduk (Garae$d d u k$ ), the major material of $d d u k b o k k i$, is one of various rice cakes in Korea. Garae-dduk is manufactured by kneading rice or flour in water, forming into a rod shape, and steaming at a high temperature [7].

Research studies on the quality of cheese are continuously reported. Studies on starters such as Streptococcus thermophiles, Leuconostoc sp., Lactococcus sp., Lactobacillus sp., Bifidobacterium sp., and Penicillium sp. used in cheese are representatives [1]. The major role of $\mathrm{LAB}$ in cheese fermentation is that $\mathrm{LAB}$ can decrease $\mathrm{pH}$ values by producing various organic acids. The low $\mathrm{pH}$ of cheese affects its texture and rheological properties directly related to chemical changes in the protein network of cheese curd [8]. Some LAB have proteolytic activity and can hydrolyze oligopeptides into smaller peptides and amino acids [9-12]. Each starter of cheese has individual properties, such as proteolytic activity and acid production. These starters can affect the properties of the final cheese product. Among them, proteolytic activity is a good indicator for ripening and the development of cheese flavor [13-15], but presumably a negative indicator for over ripening of cheese products. In non-melting cheese, such as cottage cheese, protease activity is used as a positive indicator [16].

Latilactobacillus curvatus is one of the generally-detected typical facultative heterofermentative LAB from fermented foods such as cheese $[17,18]$. Mikelsone et al. have reported that it is mainly detected in Krievijas cheese until ripening at 60 days [19]. There have been various reports on L. curvatus that can be referred to in this study. L. curvatus produces more amounts of organic acid than other LAB [20]. It can survive at cold chain temperature for 30 days or more on dairy products [21]. In addition, some studies have reported that $L$. curvatus isolated from cheese possesses antimicrobial activities [22,23].

Previously, many studies on cheese, such as cheese starter, flavor, and texture, have been reported [1]. However, negative effects of specific microorganism on hardening of cheese have not been reported yet. In this study, L. curvatus was isolated from cheese samples that showed hardening and its correlation with the hardening of cheese was investigated.

\section{Materials and Methods}

\subsection{Isolation and Identification of Lactic Acid Bacteria Strains from Cheese and Cheese-Ddukbokki} Rice Cake

Ddukbokki rice cake is one of the Korean traditional convenience foods, is made by soaking and kneading rice or wheat with water, steaming and shape at high temperature above $90^{\circ} \mathrm{C}$. Steaming process can kill other bacteria, including LAB, derived from grains such as rice and wheat. In Korea, shredded cheese is often added into steamed rice cake, it is called cheese- $d d u k b o k k i$ rice cake (CD). Most CD is commercialized to a cylinder shape of rice cake surrounding the shredded cheese in Korea (Figure 1). 


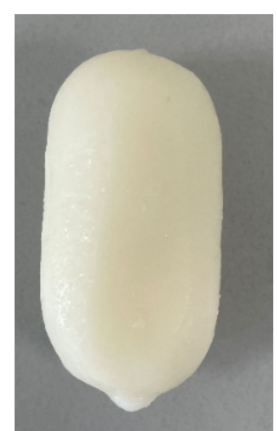

(A)

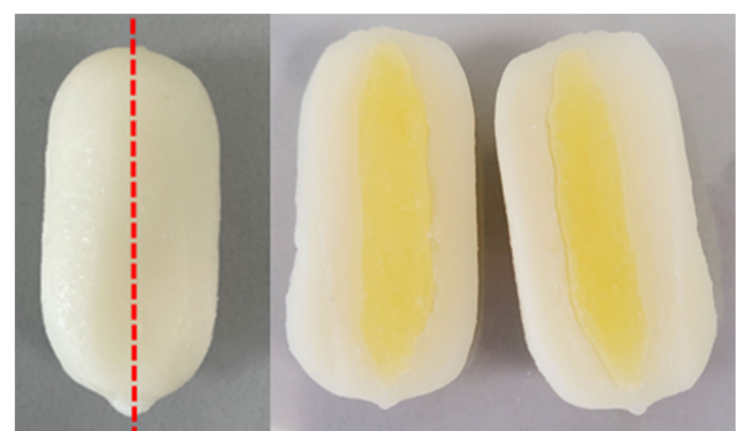

(B)

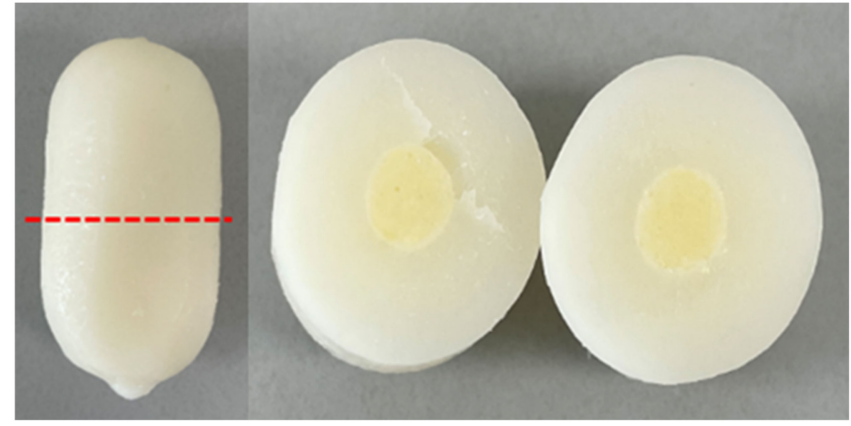

(C)

Figure 1. Structure of cheese- $d d u k b o k k i$ rice cake: (A) Whole product shape, (B) vertical section, (C) horizontal section.

Pizza Shredded II mix-5 cheese (PS5, Mozzarella cheese: Gouda cheese $=$ mixture of 4:1, material of CD samples, Maeil Dairies Co. Ltd., Gochang, Jeonbuk, Korea) was purchased at a cheese process company and a department store in Cheongju, Chungbuk, Korea from September to December of 2020. Seven cheese- $d d u k b o k k i$ rice cake (CD, Pulmuone, Goesan, Chungbuk, Korea) CD samples with different manufacturing dates were collected and used.

Twenty-five grams of CD and PS5 samples were mixed with $225 \mathrm{~mL} 0.85 \% \mathrm{NaCl}$ solution and homogenized using a stomacher (BagMixer 400, Interscience, Saint-Nom-laBretèche, France). Homogenates were diluted serially and spread onto MRS agar medium (BD, Difco, Sparks, Maryland, USA). The MRS plates were then incubated at $35{ }^{\circ} \mathrm{C}$ for $72 \mathrm{~h}$ and 30 colonies were selected randomly according to shape, and size. Selected colonies were identified by molecular biological method. 16S rRNA genes of isolates were amplified by PCR. Emerald-Amp PCR Master mix (TAKARA, Kusatsu, Shiga, Japan) was used with primer pairs: 27F (5'-AGAGTTTGATCMTGGCTCAG-3') and 1492R (5'TACGGYTACCTTGTTACGACTT-3') [24]. Thermal Cycler Dice Touch (TAKARA, Kusatsu, Shiga, Japan) was used for PCR. Sequences were determined at MACROGEN (Seoul, Korea) and analyzed using BLAST (NCBI, Bethesda, MD, USA).

\subsection{Growth Properties of Latilactobacillus Curvatus at Different Temperature Conditions}

L. curvatus isolate was initially grown in MRS broth at $35^{\circ} \mathrm{C}$ for $72 \mathrm{~h}$. The bacterial cells were inoculated $(1 \%, v / v)$ to fresh MRS broth with $2 \%(w / v)$ lactose (DUKSAN pure chemical, Ansan, Gyeonggi, Korea). These cultures were cultivated at different temperatures $(5,10$, 15,25 and $35^{\circ} \mathrm{C}$ ) for 6 days. The growth was monitored by measuring the $\mathrm{OD}_{600}$ values by micro-plate reader (infinite 200 pro, TECAN, Männedorf, Switzerland) at 5, $9 \mathrm{~h}$, then $24 \mathrm{~h}$ intervals and $\mathrm{pH}$ value was monitored with a Potentionmetric Titrator (SI Analytics, Mainz, Germany) every $24 \mathrm{~h}$. 


\subsection{Preparation of Cheese-Ddukbokki Rice Cake Containing Different Dominant Lactic Acid Bacteria}

Two types of cheese-ddukbokki rice cake containing L. curvatus PD1 or L. mesenteroides PD2 were prepared at Pulmuone R\&D center (Pulmuone Institute of Technology, Cheongju, Chungbuk, Korea). CD samples were manufactured by kneading and mixing rice flour with water and steaming at high temperature. Afterward shredded cheese was added to the steamed dough, it was re-molded in a short cylindroid shape. Cheese was added at $10 \%$ $(w / w)$ based on the weight of cheese-ddukbokki rice cake using two types of cheese samples in which L. curvatus (LC-CD) or L. mesenteroides (LM-CD) was dominant. Commerciallyavailable $\mathrm{CD}$ samples containing cheese without dominant starter were purchased as controls and used in this study. Each CD made of prepared cheese was subjected to quality test at $10^{\circ} \mathrm{C}$ for 50 days.

\section{4. $\mathrm{pH}$, Water Content and Meltability Test of Cheese-Ddukbokki Rice Cake}

Twenty-five grams of CD sample was mixed with $225 \mathrm{~mL}$ of distilled water and homogenized using BagMixer 400 (Interscience, Saint-Nom-la-Bretèche, France) with a filter bag (Whirl-Pak, Nasco, Madison, USA). The $\mathrm{pH}$ of the filtered sample was measured using a Potentionmetric Titrator (SI Analytics, Mainz, Germany). Water content of CD sample was measured for 50 days according to loss after drying by Korea Food Code [25]. Five grams of cheese was separated from CD sample and dried at $105^{\circ} \mathrm{C}$ for $5 \mathrm{~h}$ in a dry oven. Drying samples were cooled down at room temperature for $30 \mathrm{~min}$. Weights of samples were measured and water content (\%) was calculated.

Meltability test was performed for CD samples using a water bath (WiseBath, DAIHAN, Wonju, Gangwon, Korea) every 10 days during storage. Twenty grams of each CD and five grams of cheese separated from CD samples were used for the test. $C D$ and cheese samples were placed in a conical tube $(30 \times 115 \mathrm{~mm}$, SPL, Pocheon, Gyeonggi, Korea) and wrapped with aluminum-foil. These conical tubes with sample were heated at $80^{\circ} \mathrm{C}$ for $30 \mathrm{~min}$. The melting property of cheese was determined according to the appearance of cheese (melting or non-melting).

\subsection{Microbial Analysis of Cheese-Ddukbokki Rice Cake}

Microbial analysis was performed for $\mathrm{CD}$ sample every 10 days for 50 days. Twentyfive grams of $\mathrm{CD}$ was mixed with $225 \mathrm{~mL}$ of $0.85 \% \mathrm{NaCl}$ solution $(w / v)$ and homogenized using a stomacher (BagMixer 400, Interscience, Saint-Nom-la-Bretèche, France). Homogenized sample was diluted serially and spread onto MRS agar plates. MRS plates were incubated at $35^{\circ} \mathrm{C}$ for $72 \mathrm{~h}$ and 40 colonies were selected randomly according to shape, size, and color. Selected colonies were identified by molecular biological method as described in Materials and Methods Section 2.3.

\subsection{Proteolytic Activity of Lactic Acid Bacteria and Cheese-Ddukbokki Rice Cake}

Proteolytic activities of CD samples were measured according to methods by Korea Food code. Five grams of CD sample was mixed with $95 \mathrm{~mL}$ distilled water. Supernatant was obtained after centrifugation $\left(12,000 \mathrm{rpm}, 10 \mathrm{~min}, 4^{\circ} \mathrm{C}\right)$. Then $1 \mathrm{~mL}$ of supernatant sample and casein (Sigma-Aldrich, Saint Louis, MO, USA) solution $(0.6 \%, w / v)$ were mixed well and incubated at $37^{\circ} \mathrm{C}$ for $10 \mathrm{~min}$. Then $2 \mathrm{~mL}$ of $0.4 \mathrm{M}$ TCA solution was added and incubated at $37^{\circ} \mathrm{C}$ for $25 \mathrm{~min}$. Samples were filtered using a syringe filter $(0.45 \mu \mathrm{m}$, Pall Medical, New York, NY, USA). One $\mathrm{ml}$ of filtered sample was mixed with $5 \mathrm{~mL}$ of $\mathrm{Na}_{2} \mathrm{CO}_{3}$ and $1 \mathrm{~mL}$ of folin solution (3-fold dilution with distilled water, Sigma-Aldrich, Saint Louis, $\mathrm{MO}$, USA). The absorbance of sample was measured at $660 \mathrm{~nm}$ after incubating at $37^{\circ} \mathrm{C}$ for $20 \mathrm{~min}$. A standard curve was prepared using tyrosine at different concentrations. One unit of enzyme activity was expressed as the amount of enzyme that released $1 \mu \mathrm{mol}$ of tyrosine per min. Proteolytic activities of LAB isolates from shredded cheese were measured according to sigma's non-specific activity method as described previously [26]. 


\section{Results and Discussion}

\subsection{Isolation and Identification of Lactic Acid Bacteria Strains}

Fifteen of the PS5 samples and seven CD samples were collected to check whether hardening occurred during the storage period and LAB were isolated (Tables 1 and 2). Among them, strong-hardening of cheese was found for two samples and weak-hardening was found for one sample. In addition, sour-taste was observed for cheese samples showing hardening. All LAB isolates from strong-hardening samples and $40 \%$ of LAB isolates from weak-hardening sample were identified as Lactobacillus curvatus (Gene bank number of L. curvatus PD1 in this study: MW750572). On the other hand, most LAB isolates from normal cheese samples were identified as Leuconostoc mesenteroides (Gene bank number of L. mesenteroides PD2 in this study: MW750574) and Lactobacillus casei. All LAB strain's identity percentages were $99.5-100 \%$ in BLAST program. As the dominant strain in the hardening-cheese was identified as L. curvatus, we determined that this strain was an indirect cause of hardening of cheese.

Table 1. Hardening properties and Identification of LAB from cheese- $d d u k b o k k i$ rice cake samples with different manufacturing dates.

\begin{tabular}{|c|c|c|c|c|c|}
\hline Sample & $\begin{array}{c}\text { Cheese's } \\
\text { Expired Dates }\end{array}$ & Identification of LAB & $\begin{array}{c}\text { Colony Numbers } \\
\text { out of } 30\end{array}$ & $\begin{array}{c}\text { Hardening of } \\
\text { Cheese }\end{array}$ & Sour Strength \\
\hline \multirow{10}{*}{ Cheese-ddukbokki } & 13 November 2020 & Latilactobacillus curvatus & $30(100 \%)$ & Strong & Strong \\
\hline & \multirow[t]{2}{*}{13 November 2020} & Latilactobacillus curvatus & $30(100 \%)$ & \multirow[t]{2}{*}{ Strong } & \multirow[t]{2}{*}{ Strong } \\
\hline & & Lacticaseibacillus paracasei & $9(30.00 \%)$ & & \\
\hline & \multirow[t]{2}{*}{21 November 2020} & Lacticaseibacillus casei & $9(30.00 \%)$ & \multirow[t]{2}{*}{ Weak } & \multirow[t]{2}{*}{ Weak } \\
\hline & & Latilactobacillus curvatus & $12(40.00 \%)$ & & \\
\hline & \multirow{2}{*}{21 November 2020} & Leuconostoc mesenteroides & $22(73.33 \%)$ & \multirow{2}{*}{ Non-hardening } & \multirow{2}{*}{ None } \\
\hline & & Lacticaseibacillus casei & $8(26.67 \%)$ & & \\
\hline & 6 November 2020 & Leuconostoc mesenteroides & $30(100 \%)$ & Non-hardening & None \\
\hline & 26 November 2020 & Leuconostoc mesenteroides & $30(100 \%)$ & Non-hardening & None \\
\hline & 2 December 2020 & Leuconostoc mesenteroides & $30(100 \%)$ & Non-hardening & None \\
\hline
\end{tabular}

Table 2. Identification of LAB from Pizza Shredded II mix-5 cheese samples with different manufacturing dates.

\begin{tabular}{|c|c|c|c|}
\hline Sample & Manufacture Dates & Identification of LAB & $\begin{array}{c}\text { Colony Numbers } \\
\text { out of } 30\end{array}$ \\
\hline \multirow{22}{*}{$\begin{array}{l}\text { Pizza Shredded II } \\
\text { mix-5 cheese }\end{array}$} & \multirow{4}{*}{20.08 .14} & Latilactobacillus curvatus & $15(50.00 \%)$ \\
\hline & & Leuconostoc pseudomesenteroides & $9(30.00 \%)$ \\
\hline & & Lacticaseibacillus paracasei & $3(10.00 \%)$ \\
\hline & & Lacticaseibacillus casei & $3(10.00 \%)$ \\
\hline & 20.08 .22 & Latilactobacillus curvatus & $30(100 \%)$ \\
\hline & 20.08 .27 & Latilactobacillus curvatus & $30(100 \%)$ \\
\hline & 20.09 .03 & Leuconostoc mesenteroides & $30(100 \%)$ \\
\hline & \multirow{2}{*}{20.09 .18} & Leuconostoc mesenteroides & $21(70.00 \%)$ \\
\hline & & Latilactobacillus curvatus & $9(30.00 \%)$ \\
\hline & \multirow{2}{*}{20.09 .24} & Leuconostoc mesenteroides & $18(60.00 \%)$ \\
\hline & & Latilactobacillus curvatus & $12(40.00 \%)$ \\
\hline & 20.10 .02 & Latilactobacillus curvatus & $30(100 \%)$ \\
\hline & \multirow{2}{*}{20.10 .08} & Leuconostoc mesenteroides & $21(70.00 \%)$ \\
\hline & & Latilactobacillus curvatus & $9(30.00 \%)$ \\
\hline & \multirow{2}{*}{20.10 .15} & Latilactobacillus curvatus & $15(50.00 \%)$ \\
\hline & & Latilactobacillus sakei & $15(50.00 \%)$ \\
\hline & \multirow[t]{2}{*}{20.10 .26} & Latilactobacillus curvatus & $30(100 \%)$ \\
\hline & & Leuconostoc mesenteroides & $12(40.00 \%)$ \\
\hline & \multirow{2}{*}{20.11 .05} & Levilactobacillus brevis & $6(20.00 \%)$ \\
\hline & & Lacticaseibacillus casei & $12(40.00 \%)$ \\
\hline & \multirow{2}{*}{20.12 .11} & Leuconostoc mesenteroides & $15(50 \%)$ \\
\hline & & Lacticaseibacillus casei & $15(50 \%)$ \\
\hline
\end{tabular}

There are many reports of LAB used as cheese starters, such as Leuconostoc sp., Lactococcus sp., and Lactobacillus sp. Among them, L. curvatus was commonly detected from initial to 60 days of Krievijas cheese ripening. In commercial Latvian cheese samples 
(non-starter cheese), L. curvatus (28.6\%), L. paracasei subsp. paracasei (38\%), L. plantarum $(14.3 \%)$, L. rhamnosus (14.3\%), and L. acidophilus (4.8\%) were detected [27]. L. mesenteroides was the dominant acidifying strain used. L. lactis was used to improve the flavor during fermentation of dairy product.

\subsection{Growth Properties of Latilactobacillus curvatus at Different Temperature}

L. curvatus isolated from hardening cheese- $d d u k b o k k i$ rice cake was incubated at 5, 10, 15,25 , and $35^{\circ} \mathrm{C}$ for 7 days. $\mathrm{OD}_{600}$ values for growth monitoring and $\mathrm{pH}$ values were then measured at 5,9 h, then every $24 \mathrm{~h}$ (Figures 2 and 3). L. mesenteroides isolated from normal cheese- $d d u k b o k k i$ rice cake (non-hardening samples) was used as control. L. curvatus grew well at all temperature for 7 days (Figure 2A). At 15 to $35^{\circ} \mathrm{C}$, L. curvatus was better than 10 and $5^{\circ} \mathrm{C}$. L. curvatus more grew well at 25 and $15^{\circ} \mathrm{C}$, it showed that L. curvatus is one of the psychrotrophic bacteria. $\mathrm{OD}_{600}$ of L. curvatus cultures grown at $15-25{ }^{\circ} \mathrm{C}$ were the highest at $1.2674-1.3662$ on day 4 . At $10{ }^{\circ} \mathrm{C}$, L. curvatus was increased steadily, showing the highest $\mathrm{OD}_{600}$ value at $0.6240 \pm 0.02$ on day 7 . Its growth at $5{ }^{\circ} \mathrm{C}$ was slower $(0.1538 \pm 0.01$ at 7 days $)$ than under other conditions. L. mesenteroides isolated from normal CD samples grew well to $1.2289-1.2710$ at $25-35^{\circ} \mathrm{C}$ after 7 days (Figure 2B). However, $\mathrm{OD}_{600}$ at $10{ }^{\circ} \mathrm{C}$ were lower than those for L. curvatus $\left(\mathrm{OD}_{600}, 0.2169 \pm 0.03\right)$. At $5{ }^{\circ} \mathrm{C}$, the strain did not grow at $\mathrm{OD}_{600}$ values $(0.1234 \pm 0.01)$.

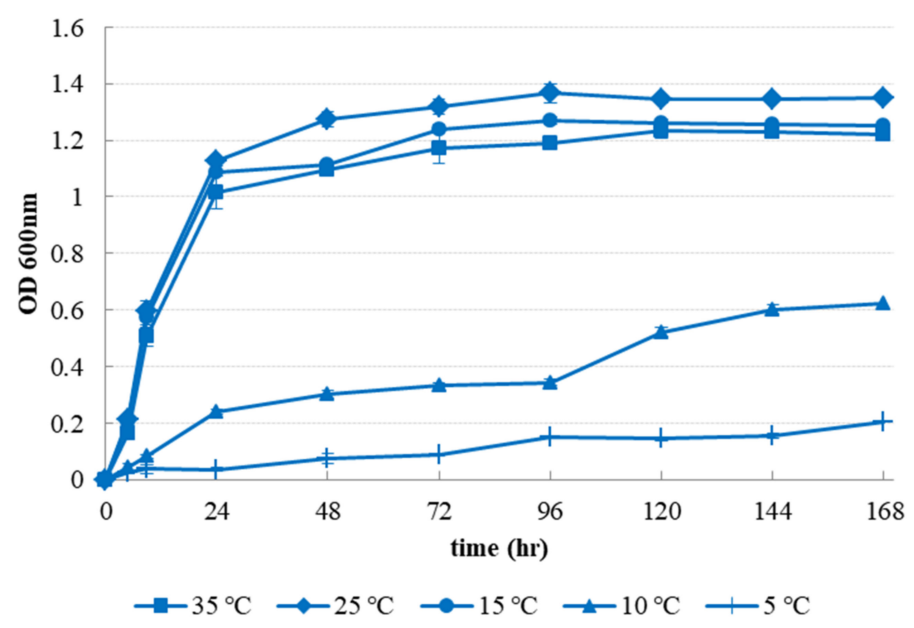

(A)

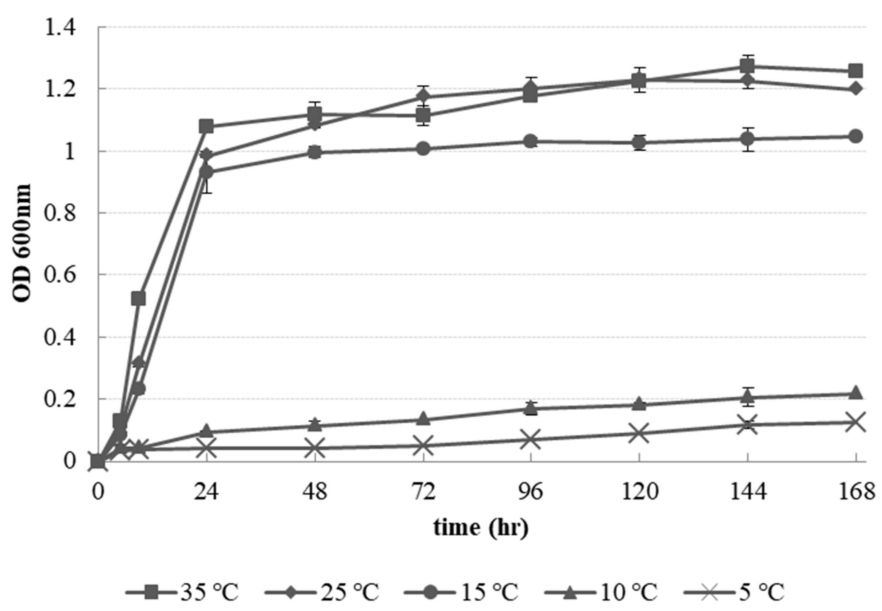

(B)

Figure 2. Growth of Latilactobacillus curvatus PD1 and Leuconostoc mesenteroides PD2 at different temperature conditions in MRS broth with lactose $(2 \%, w / v)$ for 7 days: (A) L. curvatus PD1 (B) $L$. mesenteroides PD2. 

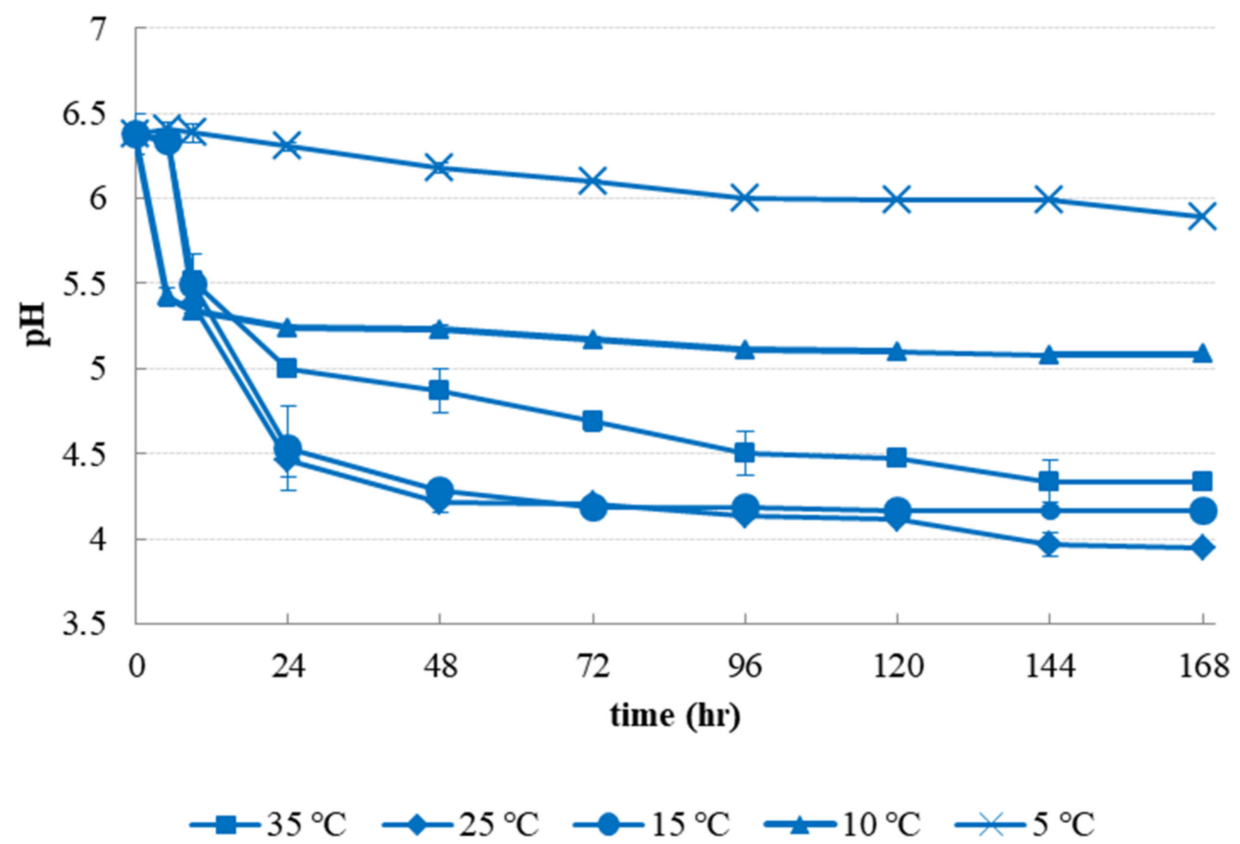

(A)

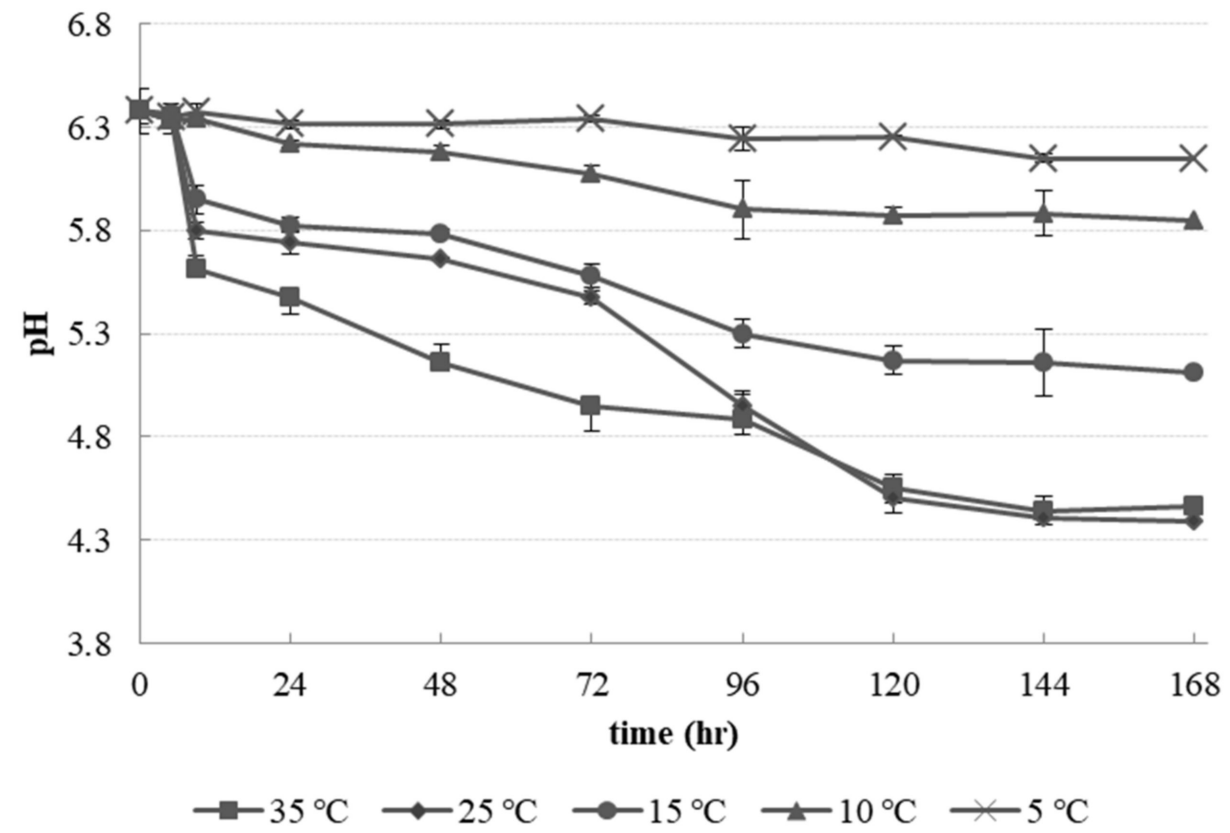

(B)

Figure 3. Change of $\mathrm{pH}$ values of Latilactobacillus curvatus PD1 and Leuconostoc mesenteroides PD2 at different temperature conditions in MRS broth with lactose $(2 \%, w / v)$ for 7 days: (A) Lactobacillus curvatus PD1 (B) Leuconostoc mesenteroides PD2.

The initial $\mathrm{pH}$ value of L. curvatus culture was $6.38 \pm 0.11$. It decreased at all temperature conditions for 7 days (Figure $3 \mathrm{~A}$ ). At $5{ }^{\circ} \mathrm{C}$, the $\mathrm{pH}$ value decreased slowly until day $7(5.89 \pm 0.01)$. It decreased to $5.08 \pm 0.01$ at $10^{\circ} \mathrm{C}$. At $15-25^{\circ} \mathrm{C}$, the lowest $\mathrm{pH}$ value was 3.94-4.16 at day 7. The $\mathrm{pH}$ value of L. mesensteroides culture was higher than that of L. curvatus at all temperature conditions (Figure 3B). The lowest $\mathrm{pH}$ value was $6.15 \pm 0.06$ for $5{ }^{\circ} \mathrm{C}, 5.85 \pm 0.07$ for $10{ }^{\circ} \mathrm{C}, 5.11 \pm 0.13$ for $15^{\circ} \mathrm{C}, 4.39 \pm 0.01$ for $25^{\circ} \mathrm{C}$, and $4.46 \pm 0.06$ for $35^{\circ} \mathrm{C}$ at 7 days. 
LAB strains usually produce lactate during growth with decreased $\mathrm{pH}$ value. It is expected that the increase of $\mathrm{LAB}$ counts is related to the decrease of $\mathrm{pH}$ value during storage. Porcellato et al. have reported that L. curvatus isolated from cheddar cheese produces various organic acids such as lactate, citrate, and acetate [17]. The genus Lactobacillus is known as one of LAB with relatively strong acid resistance and acid-producing ability compared to other genera. When Suan Cai (pickled Chinese cabbage) fermentation in Northeast China used L. curvatus as a starter, $\mathrm{pH}$ value decreased more rapidly than when L. mesenteroides was used as starter [20]. It is expected that L. curvatus will be dominant in CD sample during cold storage. It has been reported that L. cruvatus DK-13 isolated from watery Kimchi can produce high amounts of lactic acid and acetic acid during growth on MRS broth [28]. A starter of sausage, L. curvatus 54M16 can grow at a minimum $\mathrm{pH}$ of 3.5 at $30^{\circ} \mathrm{C}$. This strain has a strong acid production [29].

\section{3. $\mathrm{pH}$, Water Content, and Meltability Test of Cheese-Ddukbokki Rice Cake}

$\mathrm{pH}$ and water content (WC, \%) of cheese-ddukbokki rice cake samples were measured every 10 days until 50 days (Figure 4). The $\mathrm{pH}$ value of $\mathrm{CD}$ sample (control) gradually decreased to $5.20 \pm 0.11$ at day 50 (Figure 4A). Initial $\mathrm{pH}$ values of LC-CD and LM-CD samples were $5.67 \pm 0.09$ and $5.77 \pm 0.01$, respectively (Figure 4B,C). Initial water content of LC-CD and LM-CD samples were $46.52 \pm 0.50 \%(w / w)$ and $47.71 \pm 0.15 \%(w / w)$, respectively. The $\mathrm{pH}$ value and water content of LC-CD sample were decreased to $5.18 \pm 0.04$ and $40.05 \pm 1.63 \%(w / w)$, respectively, at day 30 . They were then decreased to $5.09 \pm 0.05$ and $37.35 \pm 0.21 \%(w / w)$, respectively, at day 50 . At 50 days, the LC-CD cheese sample did not melt in the meltability test. The $\mathrm{pH}$ value of cheese is an important indicator of the quality of cheese. It is affected by chemical interactions and structural components of cheese, such as moisture, protein, and minerals [8]. The $\mathrm{pH}$ value of cheese affects its structure and rheological properties because chemical interactions between major structural components of protein are strongly $\mathrm{pH}$ dependent. In the case of semi-rigid mozzarella and gouda shred cheese, it has been reported that these cheeses do not melt. They can easily break without being stretched when the $\mathrm{pH}$ value is less than 5.0 [30].

The quality of semi-hard and hard cheese is generally suitable when the $\mathrm{pH}$ is 5.0 to 6.0. When the $\mathrm{pH}$ is weakly acidic which increases the anionic value of the casein protein to deform the matrix, thereby improving the water holding capacity and emulsifying ability. Cheeses with $\mathrm{pH}$ below the range of 5.0-6.0 are crumbly because low $\mathrm{pH}$ can affect the protein structure, calcium phosphate, and water content. Therefore, a reduced water content of cheese affects the hardness of cheese product [31]. In this study, the used PS5 cheese is a shredded product and mixed with mozzarella and gouda, so it is suitable in similar $\mathrm{pH}$ value within the same range ( $\mathrm{pH}$ 5.0-6.0) as semi-hard and hard cheeses.

The meltability tests of $C D$ samples at day 0 to day 50 were performed by boiling in hot water for $5 \mathrm{~min}$ (Table 3). Cheese of Con-CD was not melted. It had a strong sour taste at 50 days. The $\mathrm{pH}$ value of Con-CD sample was $5.18 \pm 0.15$ at 50 days. The meltability was determined for LC-CD and LM-CD samples at an interval of 10 days until 50 days (Table 2). At 30 days, LC-CD samples were not melting. They showed crumbling (Figure 5A,C). However, LM-CD samples were melting until day 50 (Figure 5B,D). The $\mathrm{pH}$ value of LC-CD sample at day 30 was $5.18 \pm 0.04$. It decreased gradually until day 50 . Con-CD and LC-CD cheese samples did not melt. They were harder than other samples. Their $\mathrm{pH}$ values were less than 5.2. Lawrence et al. [8]. have reported that the stretchability and cohesion of natural cheese curd depend on the $\mathrm{pH}$ value. At $\mathrm{pH}$ below 5.2, small casein aggregates can bind together in long chains when heat is applied. When $\mathrm{pH}$ is at about $\mathrm{pH}$ 4.8 , cohesion and stretchability of cheese are lost. Hardening properties and $\mathrm{pH}$ changes of CD and LC-CD samples showed similar trends to those reported by Lawrence et.al. [8] 


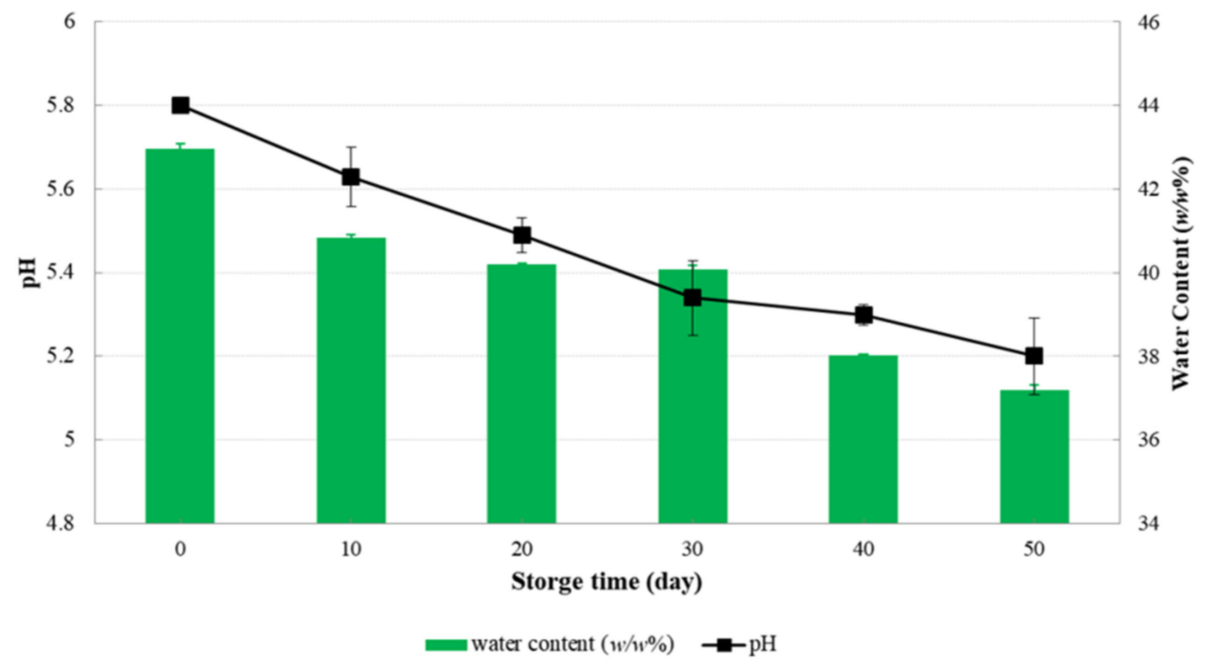

(A)

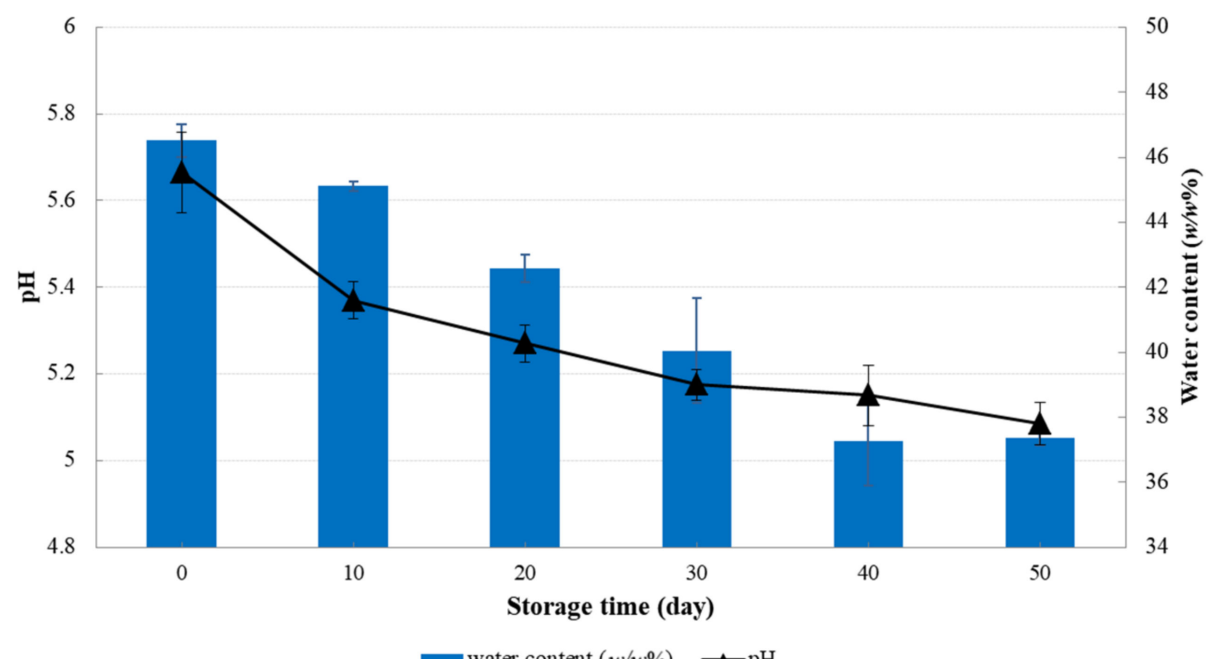

(B)

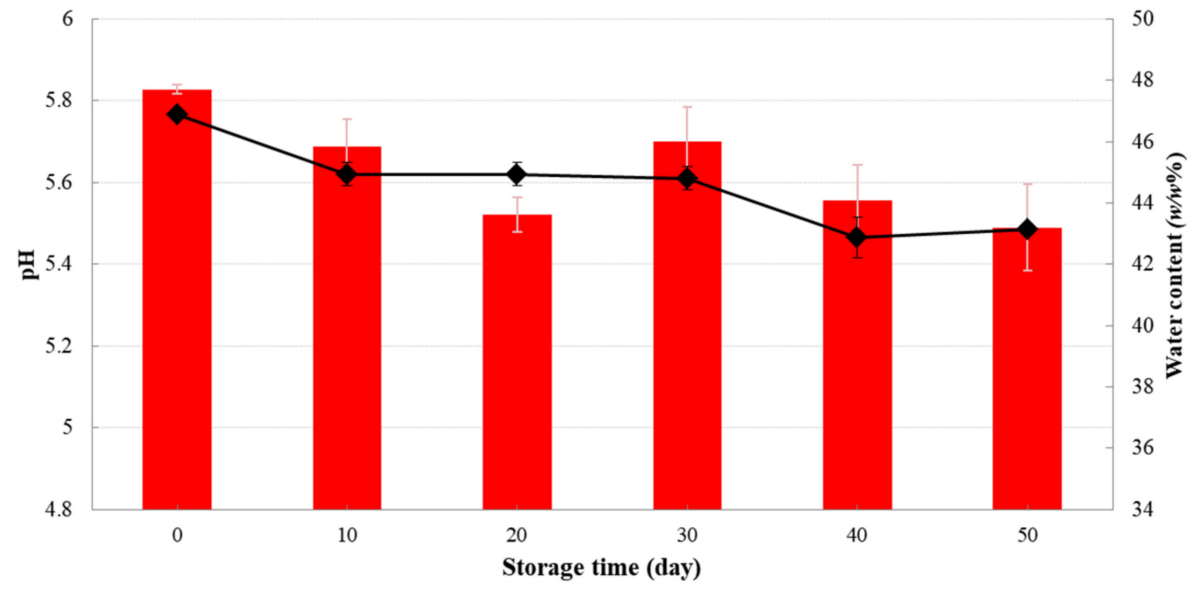

water content $(w / w \%) \rightarrow-p H$

(C)

Figure 4. $\mathrm{pH}$ and Water content (\%) of cheese-ddukbokki rice cake samples during 50 days at $10{ }^{\circ} \mathrm{C}$ : (A) Con-CD, (B) LC-CD, (C) LM-CD. 
Table 3. Meltability test of cheese- $d d u k b o k k i$ rice cake samples during 50 days at $10^{\circ} \mathrm{C}$.

\begin{tabular}{cccc}
\hline Storage Time (Day) & Con-CD $^{\mathbf{1}}$ & LC-CD $^{\mathbf{2}}$ & LM-CD $^{\mathbf{3}}$ \\
\hline 0 & Melted & Melted & Melted \\
10 & Melted & Melted & Melt \\
20 & Melted & Melted & Melted \\
30 & Melted & Non-melting & Melted \\
40 & Melted & Non-melting & Melted \\
50 & Non-melting & Non-melting & Melted \\
\hline
\end{tabular}

${ }^{1}$ Con-CD, Commercially available CD samples containing cheese with unknown dominant strains. ${ }^{2}$ LC-CD Manufacturing CD samples containing cheese with the dominant strain being Latilactobacillus curvatus. ${ }^{3} \mathrm{LM}-\mathrm{CD}$. Manufacturing CD samples containing cheese with dominant strain being Leuconostoc mesenteroides.

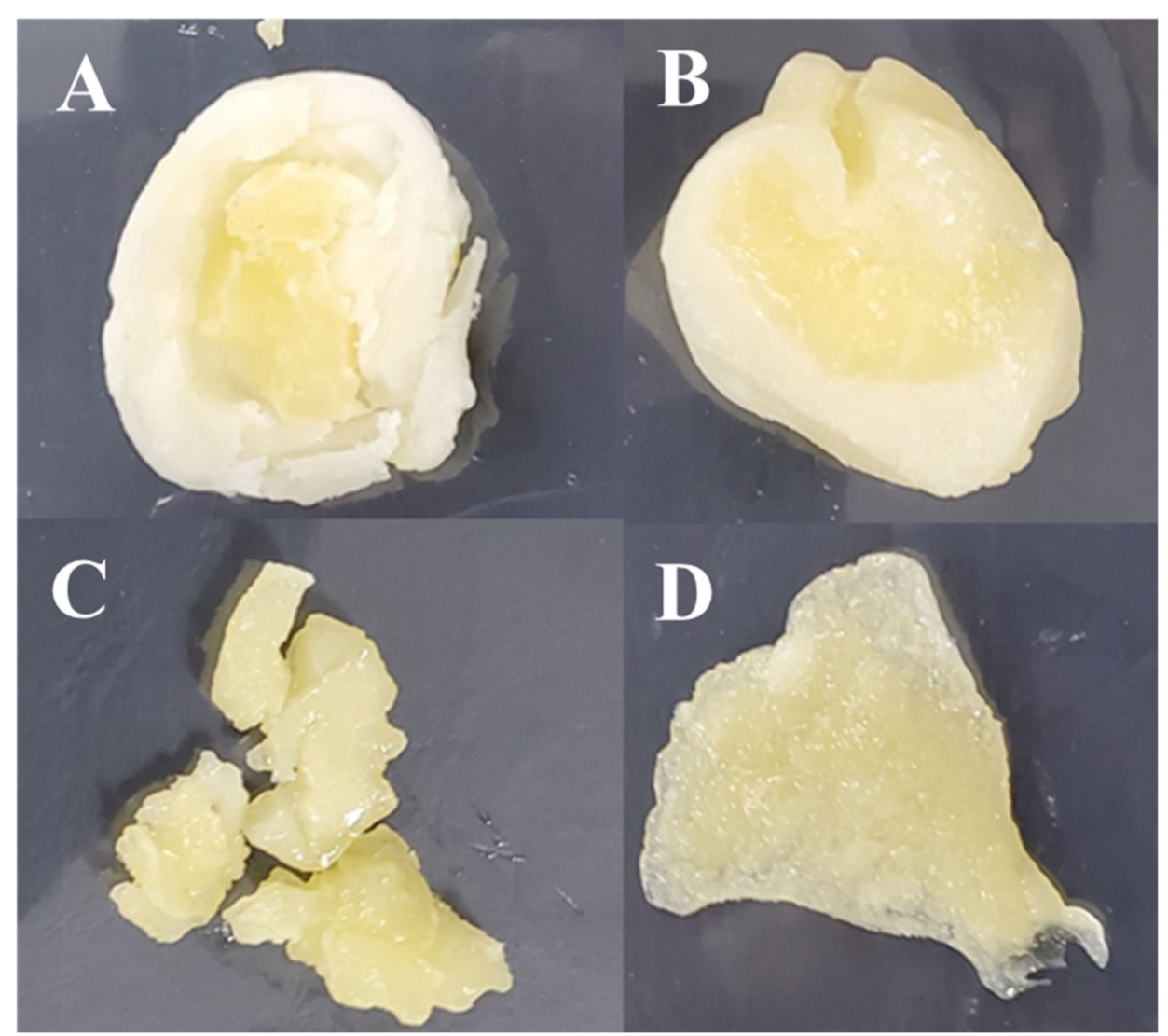

Figure 5. Meltability test of sliced LC-CD and LM-CD samples at storage times of 30 days: (A) Sliced LC-CD samples (B) sliced LM-CD samples (C), Cheese in which Lactobacillus curvatus was dominant (D) Cheese in which Leuconostoc mesenteroides was dominant.

\subsection{Microbial Analysis of Cheese-Ddukbokki Rice Cake}

Total LAB counts were determined and microbial community analyses of Con-CD samples were performed every 10 days. Results are shown in Figure 6. The initial LAB cell count of CD sample was $8.15 \log \mathrm{CFU} / \mathrm{g}$. It then increased to a count of $9.72 \mathrm{log}$ $\mathrm{CFU} / \mathrm{g}$ at 50 days. Forty colonies of LAB on MRS agar plates were randomly sequenced. Sequences were analyzed by BLAST for identification. L. mesenteroides was the most dominant group in CD sample at day 0 , accounting for $77.50 \%$ (31 out of 40 ). L. mesenteroides, a heterofermentative bacterium, is often used as a commercial cheese starter [12]. L. curvatus was the next dominant group in CD samples at day 0 (22.50\%, 9 out of 40$)$. However, as cheese storage time at 10 to 50 days, the genus Lactobacillus becomes the dominant species. At 10 days, L. paracasei was the most dominant group $(67.6 \%, 27$ out of 40$)$ and L. curvatus appeared as the most dominant species after 20 days of storage time. In particular, after 40 days, all strains were identified as L. curvatus. 


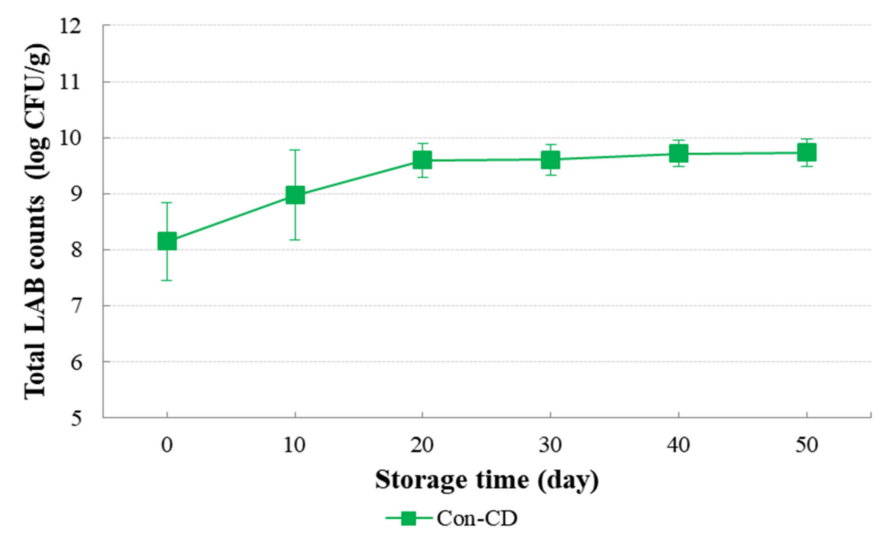

(A)

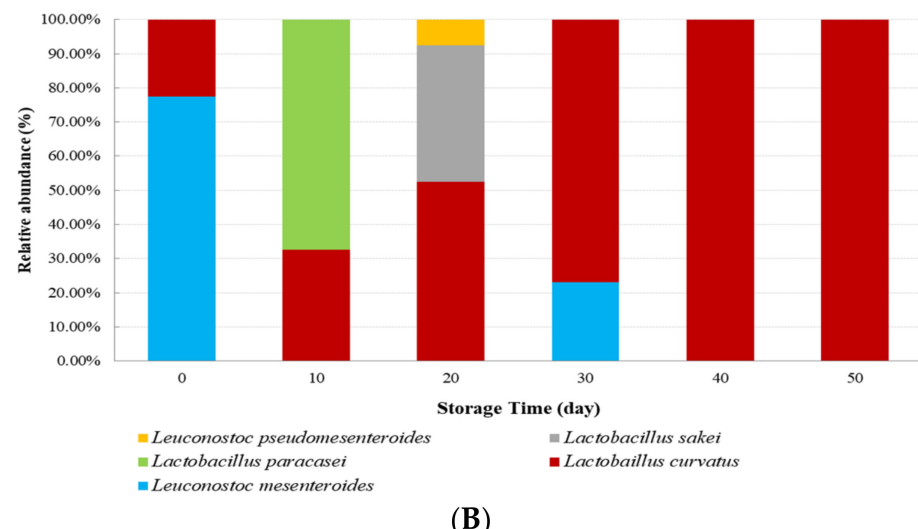

(B)

Figure 6. Total lactic acid bacteria cell counts and microbial community of Con-CD samples during 50 day at $10{ }^{\circ} \mathrm{C}$ : (A) Total LAB counts; (B) microbial community.

Microbial community analysis results of LC-CD and LM-CD samples at 0 day and 30 days are shown in Table 4 . In initial analysis, L. curvatus and L. mesenteroides were the most dominant in LC-CD (100\%) and LM-CD sample (100\%), respectively. After 30 days, L. curvatus was still the dominant strain in LC-CD samples, whereas in LM-CD samples, L. mesenteroides and L. curvatus appeared at a ratio of 8:2. The hardening of cheese was confirmed only for LC-CD cheese samples. These results suggest that L. curvatus is the cause of hardening of cheese more than other LAB strains such as Leuconostoc sp. and Lactococcus sp.

Table 4. Microbial community of lactic acid bacteria of LC-CD and LM-CD during 30 days at $10{ }^{\circ} \mathrm{C}$.

\begin{tabular}{cccc}
\hline Sample & Storage Time(Day) & Identification of LAB & Colony Numbers out of 30 (\%) \\
\hline \multirow{2}{*}{ LC-CD } & 0 & Lactobacillus curvatus & $30 / 30(100 \%)$ \\
& 30 & Lactobacillus curvatus & $30 / 30(100 \%)$ \\
LM-CD & 0 & Leuconostoc mesenteroides & $30 / 30(100 \%)$ \\
& 30 & Leuconostoc mesenteroides & $24 / 30(80 \%)$ \\
& Lactobacillus curvatus & $6 / 30(20 \%)$ \\
\hline
\end{tabular}

L. curvatus is considered as one of psychrotophic strains. A psychrotrophic strain is defined as one that can grow at $7^{\circ} \mathrm{C}$, although its optimal growth temperature is higher than $7{ }^{\circ} \mathrm{C}$ [32]. During cold storage after milk collection, they dominate the flora. Their extracellular enzymes, mainly proteases, contribute to the spoilage of dairy products. Especially, souring flavor, gas formation, slime production, and decreased $\mathrm{pH}$ are caused by bacteria in ready-to-eat like salads, raw fish, cheese, and fruits [17]. It has been reported that $L$. curvatus can produce slits in cheddar cheese, cause spoilage of processed modifiedatmosphere-packaged (MAP) meat products, and produce biogenic amine in cold-smoked salmon and Dutch-type cheese [33-35]. 


\subsection{Proteolytic Activity of Lactic Acid Bacteria and Cheese-Ddukbokki Rice Cake}

Proteolytic activity of cheese-ddukbokki rice cake is shown in Figure 7. The proteolytic activity of Con-CD sample was $1296 \pm 50.45$ units/g at day 0. It gradually increased to $6170 \pm 144.40$ units/g at day 50. The proteolytic activity of LC-CD cheese sample increased rapidly to $4944.67 \pm 167.55$ units/g until day 30. Its proteolytic activity was higher than that of Con-CD or LM-CD cheese sample. However, at day 50 of storage, it showed a proteolytic activity similar to Con-CD sample. Proteolytic activity of LM-CD was the lowest at all storage time. Six LAB strains (L. curvatus, L. paracasei, L. casei, L. mesenteroide, L. pesudomesenteroide, and L. sakei) isolated from shredded cheese and Con-CD sample were measured for their proteolytic activities (Figure 7B). The proteolytic activity of Lactobacillus species was higher than that of other species, with L. curvatus having the highest activity at $135 \pm 18.38 \mathrm{Unit} / \mathrm{mL}$, followed by L.paracasei $(94.5 \pm 4.95 \mathrm{Unit} / \mathrm{mL})$ and L. mesenteroides ( $12.5 \pm 7.78 \mathrm{Unit} / \mathrm{mL}$ ). Generally, protease activity of LAB strain in cheese is a positive indicator of improved flavor during ripening. However, for melting-cheese such as shredded mozzarella cheese, protease activity is a negative indicator that must be carefully controlled.

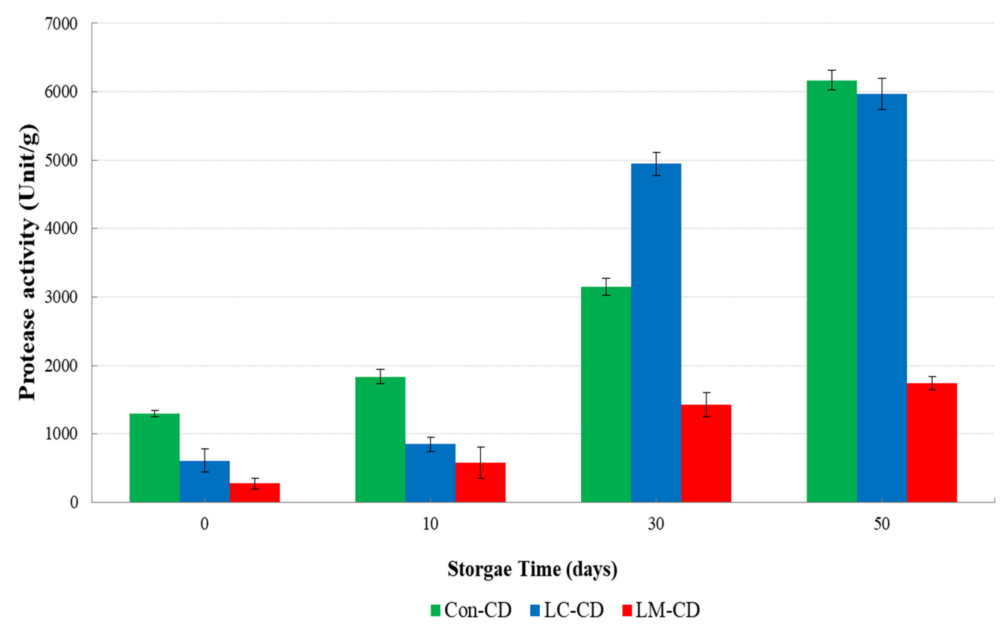

(A)

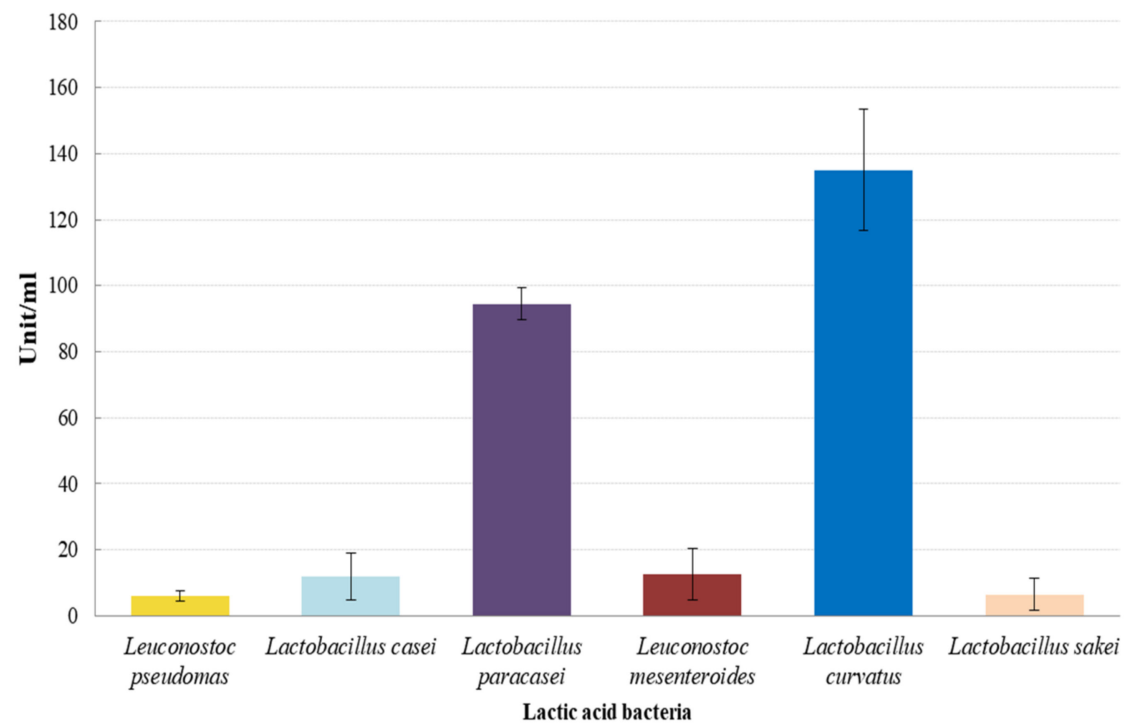

(B)

Figure 7. Proteolytic activites of $L A B$ isolates and cheese- $d d u k b o k k i$ rice cake samples: (A) Cheeseddukbokki rice cake samples at $10{ }^{\circ} \mathrm{C}$ for 50 days; (B) six LAB strains isolated from cheese-ddukbokki rice cake. 
Proteolysis is an essential process for the growth of LAB in milk and dairy products. This proteolysis provides essential free amino acids for the growth of LAB whose biosynthesis for some amino acids is limited. In addition, vitamins and minerals are produced during this biosynthesis process. Previously studies have reported that Lactobacillus sp. can produce vitamins $[3,36,37]$. Most LAB can produce a cell envelope proteinase essential for their optimal growth. Hydrolysis of cheese casein by cell envelope proteinase is considered to be the first and essential step in nitrogen metabolism by LAB [12,38]. Proteolytic activity of LAB is related to acid production and growth ability. Generally, LAB need free amino acids for growth. However, milk and dairy products, such as yogurt and cheese, have large-sized peptide and casein. LAB can break down casein to small-sized peptides and amino acids by their self-proteolytic system for growth [39].

Thus, L. curvatus in cheese-ddukbokki rice cake is expected to affect the growth of LAB due to its relatively high protease activity. As a result, casein of cheese is degraded to small molecules such as amino acids and peptides to be easily used. Thus, L. curvatus grows rapidly and produces relatively more organic acids. As a result, the $\mathrm{pH}$ value of cheese is decreased by L. curvatus and cheese-hardening of cheese- $d d u k b o k k i$ rice cake can rapidly occur at refrigerated storage.

\section{Conclusions}

In this study, various LAB strains were isolated from cheese- $d d u k b o k k i$ rice cake samples with rapid hardening. Their correlations with hardening of cheese were investigated. Among isolated LAB, L. curvatus was identified as the cause of cheese-hardening. Thus, we prepared cheese in which L. curvatus (LC-CD) or L. mesenteroides (LM-CD, non-hardening strain) was the most dominant. Each cheese- $d d u k b o k k i$ rice cake made of prepared cheese was subjected to quality test during 50 days at $10^{\circ} \mathrm{C}$. As a result, L. curvatus caused hardening of cheese faster than other LAB strains due to its high protease activity and strong production of acid. Therefore, to improve the hardening of cheese, it is essential to control (inhibit) the growth of L. curvatus. Currently we are investigating whether we could directly or indirectly utilize of LAB having antimicrobial activity against $L$. curvatus.

Author Contributions: Conceptualization, J.-A.K. and D.-Y.K.; formal analysis, J.-A.K., G.-S.K., S.-M.C. and M.-S.K.; investigation, J.-A.K. and G.-S.K.; writing original draft preparation, J.-A.K.; visualization, J.-A.K. and G.-S.K.; writing-review and editing, K.-W.L.; supervision, D.-Y.K. and K.-W.L.; project administration, S.-G.K. and S.-Y.L. All authors have read and agreed to the published version of the manuscript.

Funding: This research received no external funding.

Institutional Review Board Statement: Not applicable.

Informed Consent Statement: Not applicable.

Data Availability Statement: Not applicable.

Conflicts of Interest: The authors declare no conflict of interest.

\section{References}

1. Beresford, T.P.; Fitzsimons, N.A.; Brennan, N.L.; Cogan, T.M. Recent advances in cheese microbiology. Int. Dairy J. 2001, 11, 259-274. [CrossRef]

2. Sandine, W.E.; Elliker, P.R. Microbially induced flavours and fermented foods flavour in fermented dairy products. J. Agric. Food Chem. 1970, 18, 557-562. [CrossRef]

3. Fox, P.F. Cheese: An overview. In Cheese: Chemistry, Physics and Microbiology, 2nd ed.; Fox, P.F., Ed.; Springer: Boston, MA, USA, 1993; pp. 1-36.

4. Lee, J.; Yoon, Y. Microbiological safety concerns with dairy products from farmstead plants. J. Milk Sci. Biotechnol. 2017, 35, 215-220. [CrossRef]

5. Food Information Statistics System Home Page. Available online: https://www.atfis.or.kr/article/M001050000/list.do (accessed on 27 November 2015).

6. Eliot, S.C.; Vuillemard, J.-C.; Emond, J.-P. Stability of shredded mozzarella cheese under modified atmospheres. J. Food Sci. 1998, 63, 1075-1080. [CrossRef] 
7. Cheon, H.S.; Cho, W.-I.; Lee, S.J.; Chung, M.-S.; Choi, J.-B. Acidic and steaming treatments of tteokbokki rice cake to improve its microbial and textural properties. Korean J. Food Sci. Technol. 2017, 49, 502-506.

8. Lawrence, R.C.; Creamer, L.K.; Gilles, J. Texture development during cheese ripening. J. Dairy Sci. 1987, 70, 1748-1760. [CrossRef]

9. Fox, P.F. Proteolysis in cheese during ripening. J. Dairy Sci. 1996, 72, 1379-1400. [CrossRef]

10. Law, J.; Haandrikman, A. Proteolytic enzymes of lactic acid bacteria. Int. Dairy J. 1997, 7, 1-11. [CrossRef]

11. Christensen, J.E.; Dudley, E.G.; Pederson, J.A.; Steele, J.L. Peptidases and amino acid catabolism in lactic acid bacteria. Antoine van Leeuwenhoek 1999, 76, 217-246. [CrossRef]

12. Sousaa, M.J.; Ardo, Y.; McSweeney, P.L.H. Advances in the study of proteolysis during cheese ripening. Int. Dairy J. 2001, 11, 327-345. [CrossRef]

13. Yun, J.J.; Barbano, D.M.; Kiely, L.J.; Kindstedt, P.S. Mozzarella cheese: Impact of rod:coccus ratio on composition, proteolysis, and functional properties. J. Dairy Sci. 1995, 78, 751-760. [CrossRef]

14. Pax, A.P.; Ong, L.; Kentish, S.E.; Gras, S.L. Effects of shredding on the functionality, microstructure and proteolysis of low moisture mozzarella cheese. Int. Dairy J. 2021, 117, 104979. [CrossRef]

15. Bergamini, C.V.; Hynes, E.R.; Palma, S.B.; Sabbag, N.G.; Zalazar, C.A. Proteolytic activity of three probiotic strains in semi-hard cheese as single and mixed cultures: Lactobacillus acidophilus, Lactobacillus paracasei and Bifidobacterium lactis. Int. Dairy J. 2009, 19, 467-475. [CrossRef]

16. Williams, A.G.; Banks, J.M. Proteolytic and other hydrolytic enzyme activities in non-starter lactic acid bacteria (NSLAB) isolated from cheddar cheese manufactured in the United Kingdom. Int. Dairy J. 1997, 7, 763-774. [CrossRef]

17. Porcellato, D.; Johnson, M.E.; Houck, K.; Skeie, S.B.; Mills, D.A.; Kalanetra, K.M.; Steele, J.L. Potential of Lactobacillus curvatus LFC1 to produce slits in Cheddar cheese. Food Microbiol. 2015, 49, 65-73. [CrossRef]

18. Zheng, J.; Wittouck, S.; Salvetti, E.; Franz, C.M.A.P.; Harris, H.M.B.; Mattarelli, P.; O’Toole, P.W.; Pot, B.; Vandamme, P.; Walter J.; et al. A taxonomic note on the genus Lactobacillus: Description of 23 novel genera, emended description of the genus Lactobacillus Beijerinck 1901, and union of Lactobacillaceae and Leuconostocaceae. Int. J. Syst. Evol. Microbiol. 2020, 70, 2782-2858. [CrossRef]

19. Mikelsone, A.; Ciprovica, I. Analysis of cheese microflora. Fac. Food Technol. 2011, 2010, 96-102.

20. De Marques, J.L.; Funck, G.D.; da Dannenberg, G.S.; dos Cruxen, C.E.S.; Halal, S.L.M.E.; Dias, A.R.G.; Fiorentini, A.M.; da Silva, W.P. Bacteriocin-like substances of Lactobacillus curvatus P99: Characterization and application in biodegradable films for control of Listeria monocytogenes in cheese. Food Microbiol. 2017, 63, 159-163. [CrossRef] [PubMed]

21. Ahmadova, A.; Todorov, S.D.; Hadji-Sfaxi, I.; Choiset, Y.; Rabesona, H.; Messaoudi, S.; Kuliyev, A.; de Franco, B.D.G.M.; Chobert, J.-M.; Haertlé, T. Antimicrobial and antifungal activities of Lactobacillus curvatus strain isolated from homemade Azerbaijani cheese. Anaerobe 2013, 20, 42-49. [CrossRef] [PubMed]

22. Yang, H.; Wu, H.; Gao, L.; Jia, H.; Zhang, Y.; Cui, Z.; Li, Y. Effects of Lactobacillus curvatus and Leuconostoc mesenteroides on Suan Cai Fermentation in Northeast China. J. Microbiol. Biotechnol. 2016, 26, 2148-2158. [CrossRef] [PubMed]

23. Funck, G.D.; de Marques, J.L.; dos Cruxen, C.E.S.; Sehn, C.P.; Haubert, L.; da Dannenberg, G.S.; Klajn, V.M.; Silva, W.P.; Fiorentini, Â.M. Probiotic potential of Lactobacillus curvatus P99 and viability in fermented oat dairy beverage. J. Food Process Preserv. 2019, 43, 1-11. [CrossRef]

24. Lee, K.W.; Kim, G.S.; Baek, A.H.; Hwang, H.S.; Kwon, D.Y.; Kim, S.G.; Lee, S.Y. Isolation and characterization of Kimchi starters Leuconostoc mesenteroides PBio03 and Leuconostoc mesenteroides PBio104 for manufacture of commercial Kimchi. J. Microbiol. Biotechnol. 2020, 30, 1060-1066. [CrossRef]

25. Jeon, H.; Lee, S.; Kim, S.; Kim, Y. Quality characteristics of modified Doenjang and traditional Doenjang. J. Korean Soc. Food Sci. Nutr. 2016, 45, 1001-1009. [CrossRef]

26. Cupp-Enyard, C. Sigma's non-specific protease activity assay-Casein as a substrate. J. Vis. Exp. 2008, 19, 1-3. [CrossRef] [PubMed]

27. Mikelsone, A.; Ciprovica, I. Diversity of non-starter lactic acid bacteria in Latvian semi-hard cheeses. Res. Rural Dev. 2009, 15, 103-107.

28. Choi, M.-S.; Kim, D.-M.; Oh, K.-H. Studies on the enhanced physiological activities of mixed lactic acid bacteria isolated. Korean Soc. Biotechnol. Bioeng. J. 2015, 30, 245-252.

29. Casaburi, A.; Martino, V.D.; Ferranti, P.; Picariello, L.; Villani, F. Technological properties and bacteriocins production by Lactobacillus curvatus 54M16 and its use as starter culture for fermented sausage manufacture. Food Control 2016, 59, 31-45. [CrossRef]

30. Kindstedt, P.S.; Zielinski, A.; Almena-Aliste, M.; Ge, C. A post-manufacture method to evaluate the effect of pH on Mozzarella cheese characteristics. Aust. J. Dairy Technol. 2001, 56, 202-207.

31. Choi, C.; Lim, H.-W.; Chon, J.-W.; Kim, D.-H.; Song, K.-Y.; Kim, S.-Y.; Kim, H.; Seo, K.-H. Sensory evaluation of various gouda cheeses produced from raw milk. J. Milk Sci. Biotechnol. 2018, 36, 95-105. [CrossRef]

32. Mozzi, F. Lactic acid bacteria. In Encyclopedia of Food and Health, 1st ed.; Caballero, B., Finglas, P., Toldra, F., Eds.; Elsevier Ltd.: Amsterdam, The Netherlands, 2016; pp. 501-508.

33. Vihavainen, E.; Lundstrom, H.-S.; Susiluoto, T.; Koort, J.; Paulin, L.; Auvinen, P.; Bjorkroth, K.J. Role of broiler carcasses and processing plant air in contamination of modified-atmosphere-packaged broiler products with psychrotrophic lactic acid bacteria. Appl. Environ. Microbiol. 2006, 73, 1136-1145. [CrossRef] [PubMed] 
34. Jorgensen, L.V.; Huss, H.H.; Dalgaard, P. The effect of biogenic amine production by single bacterial cultures and metabiosis on cold-smoked salmon. J. Appl. Microbiol. 2000, 89, 920-934. [CrossRef]

35. Pachlová, V.; Buňková, L.; Flasarová, R.; Salek, R.-N.; Dlabajová, A.; Butor, I.; Buňka, F. Biogenic amine production by nonstarter strains of Lactobacillus curvatus and Lactobacillus paracasei in the model system of Dutch-type cheese. LWT 2018, 97, 730-735. [CrossRef]

36. Hugenholtz, J.; Kleerebezem, M. Metabolic engineering of lactic acid bacteria: Overview of the approaches and results of pathway rerouting involved in food fermentations. Curr. Opin. Biotechnol. 1999, 10, 492-497. [CrossRef]

37. Savijoki, K.; Ingmer, H.; Varmanen, P. Proteolytic systems of lactic acid bacteria. Appl. Microbiol. Biotechnol. 2006, 71, $394-406$. [CrossRef] [PubMed]

38. Ezzat, N.; Soda, M.E.; Shafei, H.E.; Olson, N. Cell-wall associated peptide hydrolase and esterase activities in several cheese-related bacteria. Food Chem. 1993, 48, 19-23. [CrossRef]

39. So, M.H. Influences of proteolytic ability of lactic acid bacteria on acid production and precipitates occurrence in liquid yogurt preparation. Korean J. Appl. Microbiol. Bioeng. 1984, 12, 285-291. 